\title{
Proceduralne aspekty udziału Sejmu w stanowieniu prawa UE: zakres opiniodawczej działalności sejmowej Komisji do Spraw Unii Europejskiej'
}

Udział Sejmu w tworzeniu prawa UE wyraża się głównie w sposób pośredni, czyli przez implementację tego prawa na gruncie krajowym. Główną rolę w tym procesie odgrywa wyspecjalizowany organ Sejmu: Komisja do Spraw Unii Europejskiej. Przedmiotem pracy tej Komisji są dokumenty instytucji unijnych. Należą do nich przede wszystkim projekty aktów ustawodawczych UE wydawane bezpośrednio na podstawie kompetencji traktatowych łącznie przez Radę i Parlament Europejski. Komisja wykonuje swoje kompetencje w drodze prawnej i merytorycznej analizy dokumentów, zarówno pochodzenia unijnego, jak i krajowego związanego z prawodawstwem UE.

Słowa kluczowe: komisja sejmowa, prawo, Sejm, Unia Europejska

Procedural aspects of the Sejm's participation in making of the EU law: the scope of the consultative activity of the Sejm's European Union Affairs Committee: The Sejm's participation in drafting of the EU law is mainly expressed indirectly, i.e. through the implementation of EU law on a national level. The main role in the process is played by a specialized body of the Sejm: the European Union Affairs Committee. The subject of activity of this Committee is analysing documents drafted by EU institutions. These include, in particular, draft EU legislative acts to be adopted, according to direct treaty basis, directly by the Council and the European Parliament. The Committee uses its competences by means of a legal and factual analysis of documents, both of EU and national origin, related to EU legislation.

Keywords: Committee of the Sejm, Law, Sejm, European Union

Doktor nauk prawnych, adiunkt na Uniwersytecie Kardynała Stefana Wyszyńskiego w Warszawie, naczelnik Wydziału Analiz Prawa Europejskiego i Międzynarodowego BAS ziemowit.cieslik@sejm.gov.pl • https://orcid.org/0000-0003-4345-0610

\section{Kompetencje Sejmu w dziedzinie tworzenia prawa UE}

Udział Sejmu w procedurze tworzenia prawa UE, który głównie wyraża się w pośrednim wpływie krajowego prawodawcy na proces tworzenia aktów prawa wtórnego przez instytucje unijne, jest oparty na podstawach traktatowych, zawartych w prawie pierwotnym UE, i krajowych: ustawowych oraz regulaminowych. Podstawy unijne określa art. 12 Traktatu o UE, który powierza parlamentom narodo-

$1 \quad$ Proceduralne aspekty udziału Sejmu w stanowieniu prawa UE: zakres opiniodawczej działalności sejmowej Komisji do Spraw Unii Europejskiej, opinia sporządzona 8 listopada 2019 r. na zlecenie dyrektora Biura Analiz Sejmowych; BAS-WAPM 2263/19. 
wym zadanie „aktywnego przyczyniania się do prawidłowego funkcjonowania Unii” i określa rozbudowany katalog działań, które mają być przez parlamenty narodowe podejmowane w celu realizacji tego zadania. Regulację tego przepisu rozwijają inne - powołane w nim - postanowienia traktatowe, w szczególności zawarte $\mathrm{w}$ załączonych do traktatów protokołach w sprawie roli parlamentów narodowych w Unii Europejskiej (protokół nr 1) i w sprawie stosowania zasad pomocniczości i proporcjonalności (protokół nr 2) ${ }^{2}$. Krajowe reguły udziału Sejmu w stanowieniu prawa UE określone zostały z kolei w ustawie o współpracy Rady Ministrów z Sejmem i Senatem w sprawach związanych z członkostwem Rzeczypospolitej Polskiej w Unii Europejskiej (dalej: ustawa kooperacyjna) ${ }^{3}$ i regulaminie Sejmu. Zarówno ustawa kooperacyjna, jak i regulamin Sejmu poświęcają tej problematyce wyodrębnione jednostki redakcyjne: rozdz. 2 ustawy pt. Współpraca $w$ zakresie stanowienia prawa Unii Europejskiej oraz rozdz. 13a regulaminu Sejmu pt. Komisja do Spraw Unii Europejskiej. ${ }^{4}$ Warto podkreślić, że w złożonej i wielowarstwowej regulacji, która wyznacza zasady parlamentarnego zaangażowania w proces stanowienia prawa UE, zbiegają się - i ostatecznie łączą ze sobą - podstawowe wątki i idee regulacyjne, które określają krajowy wymiar proceduralny unijnego prawotwórstwa. W efekcie to właśnie w Sejmie (i Senacie) wykuwa się praktyka ustrojowa, polegająca na współdziałaniu organów różnych krajowych władz publicznych, które są zaangażowane w proces tworzenia prawa UE.

Zgodnie $\mathrm{z}$ regułami krajowymi stanowienie prawa UE w Sejmie, a zatem pośredni udział Sejmu w tworzeniu tego prawa, to niemal wyłączna domena wyspecjalizowanego organu Sejmu - Komisji do Spraw Unii Europejskiej5. Sama izba włącza się w unijny proces prawotwórczy wyjątkowo, w bardzo szczególnych okolicznościach (tzw. kwalifikowane mechanizmy współpracy, art. 14-16 ustawy kooperacyjnej). Działania standardowe i rutynowe podejmowane są przez Komisję ds. UE (tzw. ogólny mechanizm współpracy, art. 7-8, 10-13 ustawy kooperacyjnej). Postępowanie Komisji ds. UE sprowadza się przy tym, w zasadzie, do

$2 \quad$ Szerzej zob. Z Cieślik, Rola Sejmu w stanowieniu prawa Unii Europejskiej [w:] Rola Sejmu w stanowieniu i wykonywaniu prawa Unii Europejskiej, red. B. Pawłowski, Warszawa 2015, s. 9-30.

3 Ustawa z 8 października 2010 r. o współpracy Rady Ministrów z Sejmem i Senatem w sprawach związanych z członkostwem Rzeczypospolitej Polskiej w Unii Europejskiej, Dz.U. nr 213, poz. 1395.

4 Uchwała Sejmu Rzeczypospolitej Polskiej z 30 lipca 1992 r. - Regulamin Sejmu Rzeczypospolitej Polskiej, t.j. M.P. 2012, poz. 32, ze zm. Zob. rozdz. 13a regulaminu Sejmu, w szczególności art. 148ca-art. 148cf.

5 Zbliżone rozwiązania przewiduje regulamin Senatu. Zob. uchwala Senatu Rzeczypospolitej Polskiej z 23 listopada 1990 r. - Regulamin Senatu (M.P. 2018, poz. 846), dział VIIIA Postępowanie w sprawach związanych z członkostwem Rzeczypospolitej Polskiej w Unii Europejskiej. 
wydawania opinii, które odnoszą się do: 1) określonych dokumentów UE i 2) powiązanych $\mathrm{z}$ tymi dokumentami stanowisk (informacji) Rady Ministrów. Instrumentarium prawne tej Komisji jest w tym zakresie zdeterminowane przez ustawę kooperacyjną - ustawa ta określa typy wydawanych przez nią opinii. Warto podkreślić, że choć opinie Komisji ds. UE nie są - i nie mogą być - wiążące dla Rady Ministrów (nie są ustawami), ustawa kooperacyjna przypisuje im jednak szczególny skutek. Zgodnie z jej postanowieniami opinie takie powinny stanowić podstawę stanowiska Rzeczypospolitej Polskiej i, w konsekwencji, nie mogą być ignorowane bez sankcji określonych w tej ustawie ( W przypadku gdy stanowisko [...] nie uwzględnia opinii organu właściwego na podstawie regulaminu Sejmu, członek Rady Ministrów ma obowiązek niezwłocznie wyjaśnić organowi właściwemu na podstawie regulaminu Sejmu przyczyny rozbieżności, art. 13 ustawy kooperacyjnej). Co ważne, wskazany quasiwiążący skutek opinii odnosi się do wypowiedzi Komisji na temat obu kategorii dokumentów, które stanowią przedmiot jej pracy. Warto w tym miejscu przybliżyć każdą z tych kategorii.

Po pierwsze, przedmiotem pracy Komisji ds. UE są dokumenty instytucji UE, które przekazywane są do Sejmu w wykonaniu obowiązków traktatowych (art. 1 i art. 2 protokołu nr 1). Do dokumentów tych należą przede wszystkim najważniejsze projekty aktów prawnych UE - projekty aktów ustawodawczych UE wydawane bezpośrednio na podstawie kompetencji traktatowych łącznie przez Radę i Parlament Europejski. Dodatkowo komisja bada również dokumenty konsultacyjne UE, a zatem, w szczególności, zielone księgi, białe księgi, komunikaty oraz sprawozdania Komisji Europejskiej. Generalnie, w grę wchodzą projekty wiążącego prawa UE (hard law) i akty niewiążące (soft law) ${ }^{6}$. W praktyce parlamentarnej wszystkie dokumenty, które Sejm otrzymuje bezpośrednio od organów UE i które są następnie rozpatrywane przez Komisję ds. UE, określane są - nieugruntowanym wyraźnie w tekstach aktów prawnych - mianem dokumentów UE.

Po drugie, dokumentom UE towarzyszą dokumenty krajowe sporządzane przez Radę Ministrów w wykonaniu obowiązków, które nakłada na nią ustawa kooperacyjna (art. 7 ust. 1 i ust. 2, art. 8 ust. 1, art. 10 ust. 1, art. 11 ust. 1 i art. 3 ust. 2). Przede wszystkim do każdego projektu aktu ustawodawczego UE Rada Ministrów obowiązana jest dosłać do Sejmu opracowany przez siebie (ściślej przez działający w jej imieniu na podstawie ustawowej delegacji rządowy Komitet ds. Europejskich) ${ }^{7}$ projekt stanowiska RP. Ponadto do każdego dokumentu

6 Warto odnotować, że od wejścia w życie traktatu z Lizbony - w związku ze zmianami prawa pierwotnego, które wówczas nabrały mocy - parlamentom narodowym przestano zasadniczo przesyłać projekty innych (wiążących) aktów prawa UE niż aktów ustawodawczych. W efekcie Komisja ds. UE niemal w ogóle nie zajmuje się (bardzo licznymi w praktyce) projektami aktów delegowanych i wykonawczych, które wydaje Komisja Europejska.

7 Art. 3 ustawy z 27 sierpnia 2009 r. o Komitecie do Spraw Europejskich, t.j. Dz.U. 2017, poz. 2078. 
konsultacyjnego może zostać sporządzona, na wniosek Komisji ds. UE, i przesłana do Sejmu informacja Rady Ministrów (art. 3 ust. 2 ustawy kooperacyjnej). W dokumentach rządowych, które dotyczą dokumentów UE, formułowane jest stanowisko rządu, które na gruncie ustawy zwane jest stanowiskiem RP, co stanowi refleks konstytucyjnej zasady, zgodnie z którą Rada Ministrów prowadzi politykę zagraniczną RP.

W największym uproszczeniu - dyspozycje i uwagi zawarte w opiniach Komisji ds. UE mają zatem za przedmiot w równej mierze dokumenty UE, jak i towarzyszące im dokumenty Rady Ministrów. Warto odnotować, że rola tych ostatnich (informacji Rady Ministrów o dokumencie UE) jako substratu oceny sejmowej jest szczególnie silna w przypadku dokumentów konsultacyjnych UE, ponieważ są one przesyłane do Sejmu już po ich ostatecznym przyjęciu przez instytucje UE, a więc po zamknięciu procedury ich stanowienia i wyczerpaniu możliwości jakiegokolwiek oddziaływania na ich kształt. A więc jedynym efektem działań Komisji ds. UE, które wiążą się z unijnymi dokumentami konsultacyjnymi (nie-legislacyjnymi), jest oddziaływanie na Radę Ministrów, czyli ogólna kontrola rządowych działań w sferze polityki zagranicznej (unijnej). Sytuacja przedstawia się inaczej w przypadku projektów aktów ustawodawczych UE - tu możliwe jest oddziaływanie parlamentu wprost na - wciąż się toczący - proces decyzyjny w UE.

\section{Wstępna selekcja dokumentów UE w Sejmie}

W praktyce Komisja ds. UE zajmuje się ok. 700 dokumentami UE rocznie (w ostatnich latach liczba ta nieco maleje). Dokumenty te docierają do Sejmu z różną intensywnością, warunkowaną natężeniem prac instytucji UE. Przykładowo, w spokojniejszym (wyborczym) tygodniu od 15-21 maja 2019 r. do Sejmu dotarło 9 dokumentów UE, w tym 4 projekty aktów prawnych i 5 dokumentów konsultacyjnych, ale już w tygodniu z początku roku kalendarzowego, w okresie 30 stycznia do 5 lutego 2019 r., wpłynęło 26 dokumentów, w tym 17 projektów aktów prawnych i 9 dokumentów konsultacyjnych. Na tle mnogości - bardzo różnorodnych pod względem treści i formy - dokumentów UE pojawia się pytanie o selekcję materiału, który podlega ocenie Komisji ds. UE. Selekcja ta wyraża się zarówno w doborze dokumentów, które poddawane są przez komisję szczegółowej analizie, jak i w doborze zagadnień, którym komisja poświęca szczególną uwagę, rozpatrując dany dokument. Reguły doboru materii, która stanowi przedmiot szczegółowych prac komisji, nie zostały ujęte w sposób wyraźny w prawie. Komisja sama rozstrzyga o sposobie wykonywania swych ustawowych kompetencji, ustawodawca pozostawił jej w tym względzie znaczną swobodę decyzyjną („organy ... mogą wydać opinię”) (art. 7 ust. 4, art. 8 ust. 2, art. 10 ust. 2 ustawy kooperacyjnej, także art. 13 ust. 1). Mimo tej swobody, selekcja dokonuje się w sposób uporządkowany - i zdyscyplinowany - ustalonym i utrwalonym 
w wielokadencyjnej praktyce zwyczajem parlamentarnym. W tym kontekście ujawnia się rola służb parlamentarnych, które - na podobieństwo służb legislacyjnych, asystujących w tworzeniu prawa krajowego - są odpowiedzialne za wsparcie prac sejmowych, których przedmiotem są działania prawotwórcze UE. Służby te sporządzają opinie o dokumentach UE, które wpływają do Sejmu, i, zgodnie ze zleceniem swego mocodawcy, poruszają w tych opiniach zagadnienia, które w ocenie Sejmu - i Komisji ds. UE - mają zasadnicze znaczenie. Według tych zagadnień uporządkowany jest typowy sposób wypowiedzi służb parlamentarnych na temat spływających do Sejmu dokumentów UE - zagadnienia te określają konstrukcję tworzonych w Sejmie opinii o dokumentach UE.

Dobór materii, która stanowi przedmiot pracy Komisji ds. UE, dokonywany jest z uwzględnieniem rekomendacji służb eksperckich Kancelarii Sejmu, które znajdują wyraz w opracowywanych przez Biuro Analiz Sejmowych biuletynach i opiniach.

Komisja ds. UE otrzymuje od służb parlamentarnych cotygodniowe zestawienie dokumentów UE („biuletyn BAS”), zawierające syntetyczną prezentację ich treści, kwalifikację formy prawnej i procedury parlamentarnej, która może znaleźć zastosowanie, oraz - przede wszystkim - rekomendację dotyczącą objęcia ich pogłębioną analizą przez Komisję ds. UE. Na podstawie biuletynu - i zawartych w nim rekomendacji - komisja oraz jej prezydium ustalają porządek prac, obejmujący dokumenty UE, które zdecydowano się rozpatrzyć podczas posiedzenia. W odniesieniu do każdego z dokumentów UE, który został w ten sposób zakwalifikowany do dalszej oceny przez Komisję ds. UE, zlecane jest opracowanie pogłębionej opinii przez BAS. To właśnie te opinie („opinie BAS o dokumentach UE”) skonstruowane są wedle - wypracowanego w praktyce parlamentarnej - schematu, który eksponuje podstawowe kwestie, będące przedmiotem zainteresowania komisji. Schemat ten jest zasadniczo jednolity - stosowany bez względu na typ ocenianego w danym przypadku dokumentu UE. W zależności od potrzeby (treści i typu ocenianego dokumentu UE) niektóre $\mathrm{z}$ wyróżnionych $\mathrm{w}$ schemacie zagadnień omawiane są w konkretnym przypadku szerzej - inne węziej, niekiedy wręcz pomijane.

Zainteresowanie Komisji ds. UE obejmuje kwestie dwojakiego rodzaju: wyróżnione ze względu na typ kompetencji poznawczej, która jest konieczna do ich właściwego rozeznania. Dokument UE oceniany jest w Sejmie w warstwie merytorycznej (treść dokumentu) i w warstwie prawnej. Refleksem tego podejścia jest wewnętrzny układ opinii, które sporządzane są na zlecenie Komisji ds. UE i dotyczą dokumentów UE. Opinie te - już na poziomie ich ogólnego schematu - dzielą się na część merytoryczną i prawną. Wstępnie można powiedzieć, że w części merytorycznej ujęty jest opis treści dokumentu UE oraz jego rzeczowa ocena (opracowana przez eksperta specjalizującego się w danej polityce UE), w części prawnej - rozważane są (przez eksperta prawnika) podstawowe kwestie dotyczące formalnych cech dokumentu (kwestie traktatowe i ustawowe, przede wszystkim proceduralne). Komisja ds. UE korzysta z tych ustaleń, rozpatrując dokument UE podczas swego posiedzenia. 


\section{Merytoryczna ocena dokumentów UE}

Komisja ds. UE koncentruje się przede wszystkim na merytorycznej ocenie dokumentu UE - a więc na ocenie polityki UE, która znajduje wyraz w danym dokumencie. Właściwą ocenę poprzedza rekonstrukcja treści dokumentu - w zależności od przypadku treść ta ma charakter regulacyjny (projekty aktów prawnych UE) albo opisowy (dokumenty konsultacyjne). Warto odnotować, że w swoich pracach komisja uwzględnia brak ostrej granicy między dokumentami regulacyjnymi a - formalnie - opisowymi. System źródeł prawa UE zna (egzotyczną z perspektywy systemu źródeł prawa Konstytucji RP) kategorię źródeł prawa niemających mocy wiążącej (unijnego soft law), do której zaliczane są nie tylko - wyraźnie wskazane w art. 288 Traktatu o funkcjonowaniu Unii Europejskiej (dalej: TFUE): opinie i zalecenia, ale także m.in. tzw. komunikaty wyjaśniające, a zatem dokumenty konsultacyjne, które prezentują wykładnię aktów wiążących, która jest przyjmowana przez organy stosujące prawo unijne (typowo - przez Komisję Europejską). Mimo formalnie opisowego charakteru tych dokumentów, badana jest również ich (ewentualna) warstwa regulacyjna, w szczególności zachęty do stosowania wiążącego prawa UE w określony sposób.

$\mathrm{Z}$ założenia treść dokumentu ustalana jest ze wskazaniem na istotę zmiany w stosunku do stanu dotychczasowego, zwłaszcza w przypadku projektów aktów prawnych. Gdy opinia dotyczy projektu aktu prawnego, który znajduje się na zawansowanym stadium postępowania prawotwórczego w UE (np. przy zmianie projektu aktu ustawodawczego, art. 293 ust. 2 TFUE), zaakcentowane są także różnice w stosunku do projektu w jego wersji pierwotnej. Standardowo w ramach opisu prezentowana jest ponadto geneza dokumentu UE i jego szerszy kontekst regulacyjny. Ustalenia dotyczą związków danego dokumentu z określonymi politykami UE, przywoływane są także unijne akty programowe, które odnoszą się do poruszanych w tym dokumencie zagadnień (konkluzje Rady Europejskiej, zielone i białe księgi, komunikaty Komisji itp.). Ostatni element opisu stanowi informacja o stanie prawa obowiązującego w Polsce, które dotyczy materii objętych treścią dokumentu UE.

Właściwa ocena dokumentu UE odnosi się do jego skutków społecznych, gospodarczych i finansowych, niekiedy także prawnych ${ }^{8}$. Punkt odniesienia oceny sejmowej stanowią informacje zawarte w samych dokumentach UE i w opracowaniach instytucji unijnych, które tych dokumentów dotyczą i nie podlegają przesłaniu parlamentom narodowym, lecz wyłącznie publikacji na stronach internetowych UE (np. dokumenty robocze służb Komisji Europejskiej, oceny skutków regulacji). Ważnym punktem odniesienia dla Komisji ds. UE są także stanowiska (informacje) Rady Ministrów na temat dokumentu UE. Członkowie

8 Na przykład wobec projektu decyzji Rady Europejskiej w sprawie skorzystania z mechanizmu $\mathrm{z}$ art. 48 ust. 7 TUE, tzw. mechanizmu kładki. 
Komisji ds. UE wyrabiają sobie zdanie o dokumencie UE na podstawie informacji pochodzących z trzech źródeł: od instytucji UE, Rady Ministrów (prezentacja dokumentu przez przedstawiciela rządu otwiera każdy punkt posiedzenia, poświęcony dokumentowi UE) oraz własnych służb eksperckich i prawnych. Na tej podstawie formułowane są przez nich pytania dotyczące dokumentu UE i ujętej w jego treści polityki UE, które zadawane są obecnemu na posiedzeniu przedstawicielowi Rady Ministrów. Na tych informacjach opiera się też ostatecznie opinia komisji, podsumowująca debatę na temat dokumentu UE.

Integralną częścią opinii Komisji ds. UE jest akceptacja bądź brak akceptacji stanowiska RP, prezentowanego przez Radę Ministrów w odniesieniu do opiniowanego dokumentu UE. Schemat opinii zlecanych przez komisję wyraźnie uwzględnia również ten element. Komisja może także sformułować w opinii zalecenia dla Rady Ministrów (art. 148c ust. 2 regulaminu Sejmu). W tym wymiarze działania Komisji ds. UE wpisują się w model tradycyjnych działań kontrolnych względem Rady Ministrów i administracji rządowej. Adresatem opinii wydawanych przez nią na podstawie ustawy kooperacyjnej jest Rada Ministrów do kręgu tych adresatów nie należą, w szczególności, prawotwórcze organy UE (Rada ani Parlament Europejski).

$\mathrm{Na}$ marginesie tych ustaleń warto odnotować, że to ograniczenie, a więc możliwość oddziaływania na politykę unijną zasadniczo wyłącznie za pośrednictwem Rady Ministrów, odbierana jest w Sejmie jako poważny deficyt, który jest tym bardziej dotkliwy, że Sejm, śladem Trybunału Konstytucyjnego (wyrok TK z 12 stycznia 2005 r., sygn. akt K 24/04), odczytuje swój udział w unijnych procedurach prawotwórczych jako wyraz sprawowania własnej funkcji ustawodawczej. Z tego powodu Sejm angażuje się niekiedy, podobnie jak inne parlamenty narodowe UE, w nieformalny dialog polityczny na szczeblu UE. Zaangażowanie to, inspirowane ze strony unijnej w 2006 r. przez przewodniczącego Komisji Europejskiej José M. Barroso ${ }^{9}$, polega na przesyłaniu opinii Komisji ds. UE do wiadomości bezpośrednio instytucjom unijnym (najczęściej Komisji Europejskiej). Choć działanie to znajduje tylko bardzo wątłe - i wątpliwe - podstawy w polskim prawie ustrojowym (art. 110 ust. 2 Konstytucji w związku z art. 10 ust. 1 pkt 10a regulaminu Sejmu), praktyka sejmowa w tym zakresie - bardzo ostrożnie - od lat się rozwija: Sejm przesyła rocznie do Brukseli w ramach dialogu polityczne-

9 W myśl inicjatywy przewodniczącego Komisji Europejskiej J.M. Barroso, która została sformułowana w 2006 r., parlamenty narodowe państw członkowskich UE są zachęcenie do zajmowania stanowisk w sprawach dotyczących inicjatyw Unii Europejskiej i przesyłania tych stanowisk organom UE. W odróżnieniu od procedur określonych w traktacie z Lizbony (kontrola poszanowania zasady pomocniczości), problematyka dialogu politycznego nie została wyraźnie uregulowana w prawie UE. Jest to inicjatywa polityczna. Zob. COM(2006) 211 final, por. opracowania dotyczące dialogu politycznego w „Przeglądzie Sejmowym” 2014, nr 3, s. 147 i n. 
go kilka opinii (od 1-5, ostatnio po posiedzeniu 12 września 2018 r. w sprawie trzech projektów rozporządzeń dotyczących wspólnej polityki rolnej) ${ }^{10}$.

Jedyną kompetencją traktatową, która umożliwia Sejmowi nawiązanie bezpośrednich relacji z instytucjami UE oraz bezpośrednie oddziaływanie na proces tworzenia prawa UE, jest uprawnienie każdej izby parlamentu narodowego do zgłoszenia uzasadnionej opinii o zgodności projektowanego prawa UE z zasadą pomocniczości (art. 12 lit. b TUE, art. 6 protokołu nr 2). Kompetencja ta ujęta jest jednak w prawie pierwotnym bardzo wąsko - i to w wielu wymiarach. Parlamentarne zastrzeżenia dotyczące zgodności z zasadą pomocniczości mogą dotyczyć - spośród wszystkich dokumentów UE - wyłącznie projektów aktów ustawodawczych i to tych tylko, które stanowione są w dziedzinie kompetencji niewyłącznych UE. Zakres bezpośredniej kontroli parlamentarnej prawotwórstwa unijnego ogranicza dodatkowo samo kryterium badania - z racji samej swej natury. Zasada pomocniczości stanowi, z jednej strony, pojęcie bardzo niedookreślone, niełatwe do prawniczego zastosowania (wedle niektórych: kryterium polityczne). Z drugiej strony zasada ta jest na gruncie traktatowym wyraźnie odróżniana od innych, bliskich jej treściowo zasad prawnych: zasady przyznania i zasady proporcjonalności (których parlamentarna kompetencja nie dotyczy). Kompetencja kontrolna ograniczona jest wreszcie terminem - można ją reali-

10 Wniosek w sprawie rozporządzenia Parlamentu Europejskiego i Rady ustanawiającego przepisy dotyczące wsparcia na podstawie planów strategicznych sporządzanych przez państwa członkowskie w ramach wspólnej polityki rolnej (planów strategicznych WPR) i finansowanych z Europejskiego Funduszu Rolniczego Gwarancji (EFRG) i z Europejskiego Funduszu Rolnego na rzecz Rozwoju Obszarów Wiejskich (EFRROW) oraz uchylającego rozporządzenie Parlamentu Europejskiego i Rady (UE) nr 1305/2013 i rozporządzenie Parlamentu Europejskiego i Rady (UE) nr 1307/2013, (COM(2018) 392 final) i odnoszący się do niego projekt stanowiska RP,

wniosek w sprawie rozporządzenia Parlamentu Europejskiego i Rady w sprawie finansowania wspólnej polityki rolnej, zarządzania nią i monitorowania jej oraz uchylającego rozporządzenie (UE) nr 1306/2013 (COM(2018) 393 final) i odnoszący się do niego projekt stanowiska RP,

wniosek w sprawie rozporządzenia Parlamentu Europejskiego i Rady zmieniającego rozporządzenia (UE) nr 1308/2013 ustanawiające wspólną organizację rynków produktów rolnych, (UE) nr 1151/2012 w sprawie systemów jakości produktów rolnych i środków spożywczych, (UE) nr 251/2014 w sprawie definicji, opisu, prezentacji, etykietowania i ochrony oznaczeń geograficznych aromatyzowanych produktów sektora wina, (UE) nr 228/2013 ustanawiające szczególne środki w dziedzinie rolnictwa na rzecz regionów najbardziej oddalonych w Unii Europejskiej i (UE) nr 229/2013 ustanawiające szczególne środki dotyczące rolnictwa dla mniejszych wysp Morza Egejskiego (COM(2018) 394 final) i odnoszący się do niego projekt stanowiska RP - rozpatrzone w trybie art. 151 ust. 1 regulaminu Sejmu, referował podsekretarz stanu w Ministerstwie Rolnictwa i Rozwoju Wsi Ryszard Zarudzki, poseł sprawozdawca Kazimierz Gołojuch. 
zować w ciągu 8 tygodni od przesłania parlamentowi ocenianego projektu aktu ustawodawczego UE.

W efekcie tych ograniczeń, mimo licznych i szumnych deklaracji o znaczeniu lizbońskich kompetencji parlamentów narodowych (zwłaszcza w kontekście zjawiska deficytu demokracji w UE), parlamenty nieczęsto sięgają po nowe uprawnienie. Sejm zgłosił dotychczas (w ciągu już niemal 10 lat od wejścia w życie traktatu $\mathrm{z}$ Lizbony) 23 uzasadnione opinie, $\mathrm{w}$ tym $4 \mathrm{w}$ bieżącej kadencji ${ }^{11}$, nie odstając tym rezultatem znacznie od ogólnounijnego standardu ${ }^{12}$. Co więcej, tylko trzy razy uzasadnione opinie parlamentów narodowych, dotyczące określonego projektu aktu ustawodawczego UE, osiągnęły próg żółtej kartki (1⁄3 głosów parlamentów narodowych), który wyzwala traktatowe skutki naruszenia zasady pomocniczości w ramach postępowania legislacyjnego $\mathrm{UE}^{13}$. W żadnym $\mathrm{z}$ tych trzech przypadków argumenty parlamentów narodowych, dotyczące naruszenia zasady pomocniczości, nie zostały uznane i podjęte przez Komisję Europejską. Generalnie więc instrumentowi temu

11 Wniosek dotyczący dyrektywy Parlamentu i Rady zmieniający dyrektywę 96/71/WE Parlamentu Europejskiego i Rady z 16 grudnia 1996 r. dotyczącej delegowania pracowników w ramach świadczenia usług, $\operatorname{COM(2016)~} 128$ final,

wniosek dotyczący rozporządzenia Parlamentu Europejskiego i Rady w sprawie ustanowienia kryteriów i mechanizmów ustalania państwa członkowskiego odpowiedzialnego za rozpatrzenie wniosku o udzielenie ochrony międzynarodowej złożonego w jednym z państw członkowskich przez obywatela państwa trzeciego lub bezpaństwowca (wersja przekształcona), COM(2016) 270 final,

wniosek dotyczący rozporządzenia Parlamentu Europejskiego i Rady w sprawie wewnętrznego rynku energii elektrycznej, $\operatorname{COM}(2016) 861$ final,

wniosek dotyczący dyrektywy Parlamentu Europejskiego i Rady w sprawie równowagi między życiem zawodowym a prywatnym rodziców i opiekunów oraz uchylającej dyrektywę Rady 2010/18/UE, COM(2017) 253 final.

12 Na przykład w roku 2017 parlamenty narodowe UE przedstawiły łącznie 52 uzasadnione opinie, które odnosiły się do 23 projektów aktów ustawodawczych UE, w tym w przypadku 12 projektów uzasadnioną opinię zgłosiła tylko jedna izba. Zob. załącznik do sprawozdania Komisji: Sprawozdanie roczne za rok 2017 w sprawie stosowania zasad pomocniczości i proporcjonalności, COM(2018) 490 final.

13 Wniosek dotyczący rozporządzenia Rady w sprawie wykonywania prawa do podejmowania działań zbiorowych w kontekście swobody przedsiębiorczości i swobody świadczenia usług, COM(2012) 130 final (niekwestionowany przez Sejm i Senat, wycofany przez Komisję Europejską z innych przyczyn),

wniosek dotyczący rozporządzenia Rady w sprawie ustanowienia Prokuratury Europejskiej, $\operatorname{COM(2013)} 534$ final (niekwestionowany przez Sejm i Senat, uchwalony przez Radę i Parlament Europejski),

wniosek dotyczący dyrektywy Parlamentu Europejskiego i Rady zmieniającej dyrektywę 96/71/WE Parlamentu Europejskiego i Rady z 16 grudnia 1996 r. dotyczącą delegowania pracowników w ramach świadczenia usług, $\operatorname{COM(2016)~} 128$ final (kwestionowany m.in. przez Sejm i Senat, uchwalony przez Radę i Parlament Europejski). 
brak jest skuteczności, co - jak się wydaje - jest związane głównie z niedostateczną współpracą między parlamentami narodowymi na etapie opiniowania projektów aktów ustawodawczych UE (podczas traktatowych 8 tygodni). Taka współpraca powinna (jako konieczny warunek skuteczności kompetencji) obejmować uzgodnienia dotyczące stanowisk w sprawie rozpatrywanych projektów - w konsekwencji: skoordynowanie zarzutów (więc ujednolicenie „parlamentarnej” koncepcji pomocniczości). Wiele wskazuje na to, że odrębności między parlamentami (ustrojowe, kulturowe, polityczne) są zbyt wielkie, by - przynajmniej na gruncie obowiązującego prawa - rezultat ten mógł zostać kiedykolwiek osiągnięty. Niewątpliwie jednak trwałym - i rzeczywistym - rezultatem stosowania testu pomocniczości przez parlamenty narodowe jest wzrost znaczenia nieformalnej (i niezobowiązującej) współpracy w ramach dialogu politycznego. Wobec braku formalnej skuteczności uzasadnione opinie parlamentów narodowych stały się (wyłącznie) dodatkową formą politycznego - nieskoordynowanego i niesformalizowanego - oddziaływania poszczególnych izb parlamentów narodowych na unijny proces decyzyjny.

Mimo tych zastrzeżeń nominalne znaczenie testu pomocniczości powoduje, że test ten został na trwałe wkomponowany w krajową procedurę parlamentarną dotyczącą udziału Sejmu w procesie tworzenia prawa UE (art. 7 ust. 3 pkt 3 ustawy kooperacyjnej, art. $148 \mathrm{cc}$ regulaminu Sejmu). W rezultacie ocena zgodności z zasadą pomocniczości formułowana jest (jako wyodrębniony punkt wypowiedzi) w każdej opinii o dokumencie UE, która sporządzana jest na zlecenie Komisji ds. UE. Obowiązek zajęcia wyraźnego stanowiska w tej mierze spoczywa także na Radzie Ministrów. Parlamentarna praktyka orzecznicza, dotycząca tej kwestii, jest więc już bogata i stanowi przedmiot pogłębionych analiz doktrynalnych ${ }^{14}$ ciągle jednak przypomina ćwiczenie w wykonywaniu przyszłych, ewentualnych kompetencji parlamentarnych, które wiązałyby się z (postulowanym przez wielu) poważniejszym umocnieniem roli parlamentów narodowych w UE niż działania władzy, która jest powołana do stanowienia prawa. Warto w tym kontekście odnotować, że koncepcji zasady pomocniczości nie uzgodniono nawet w relacjach między obiema izbami polskiego parlamentu - Sejmem i Senatem.

\section{Prawna ocena dokumentów UE}

Merytoryczną ocenę dokumentu UE uzupełnia ocena jego formalnoprawnych aspektów. Analiza w tym zakresie skupia się na czterech zagadnieniach: a) unijnej kompetencji do podejmowania określonych działań, b) ewentualnym wpływie

14 Parlamenty narodowe wobec zasady pomocniczości w świetle prawa i praktyki Unii Europejskiej, red. C. Mik, Warszawa 2019, passim; D. Adamiec, Prawne aspekty kontroli zasady pomocniczości przez parlamenty państw członkowskich Unii Europejskiej, Warszawa 2018, passim. 
dokumentu UE na prawo polskie oraz proceduralnym statusie tego dokumentu zarówno na gruncie c) unijnego postępowania prawotwórczego, jak i w świetle - stanowiących jego krajowy refleks - d) trybu postępowania Komisji ds. UE, który wynika z ustawy kooperacyjnej i regulaminu Sejmu.

W odniesieniu do kompetencji UE uwaga Komisji ds. UE koncentruje się na traktatowej (rzadziej - zawartej w prawie wtórnym UE) podstawie prawnej aktu, który stanowi treść dokumentu UE. Oceniając tę podstawę, Sejm (działający w tej mierze za pośrednictwem Rady Ministrów, której przedstawiciele bezpośrednio uczestniczą w tworzeniu prawa UE w Radzie) włącza się w kontrolę przestrzegania traktatowej zasady przyznania przez UE. Ustalenia dotyczące podstawy prawnej mają pierwszorzędne znaczenie w przypadku projektów aktów prawnych UE.

Publikacja dokumentów konsultacyjnych UE przez instytucje UE dokonuje się w sposób odformalizowany. Brak jest określonej procedury w tym zakresie (wyjątek stanowią niektóre sprawozdania, których publikacji wymagają szczególne przepisy prawa UE). W takich przypadkach Komisja ds. UE bada więc wyłącznie, czy treść dokumentu mieści się w zakresie polityk UE.

Tok ustaleń dotyczących podstawy prawnej jest uporządkowany - i przyjmuje postać rekonstrukcji podstawy wskazanej przez inicjatora procedury prawodawczej (najczęściej Komisję Europejską) i następnie oceny na jej tle treści projektowanego aktu unijnego. $\mathrm{W}$ wersji kompletnej badana jest a) kompetencja UE do podejmowania określonych działań, b) kompetencja określonych organów $\mathrm{UE}, \mathrm{c})$ zachowanie wymogów proceduralnych, które są związane $\mathrm{z}$ właściwą procedurą i d) zgodność projektowanego aktu z materialną regulacją prawa UE (przede wszystkim zasadami traktatowymi). Na tle tych ustaleń wyraźnie formułowana jest kwalifikacja prawna danego dokumentu UE: typ kompetencji UE, która stanowi jego podstawę (kompetencja wyłączna, dzielona, uzupełniająca) i forma prawna aktu, który jest zawarty w jego treści (akt wiążący, niewiążący, ustawodawczy, nieustawodawczy). Tę część analizy kończy konkluzja dotycząca legalności działań podejmowanych przez UE.

Warto odnotować, że przypadki naruszeń podstaw traktatowych identyfikowane są przez Komisję ds. UE bardzo rzadko. Najczęściej wątpliwości dotyczą postanowień projektów aktów ustawodawczych, które określają podstawy wydawania aktów delegowanych. Zgodnie z art. 290 ust. 1 TFUE akty ustawodawcze mogą przekazywać Komisji Europejskiej uprawnienia do przyjęcia aktów delegowanych, który uzupełniają lub zmieniają inne niż istotne elementy aktu ustawodawczego. W ocenie Sejmu - oraz innych parlamentów narodowych i Parlamentu Europejskiego - Komisja korzysta niekiedy z tej kompetencji nader swobodnie, uznając za nieistotne np. postanowienia, które determinują zakres zastosowania aktu ustawodawczego ${ }^{15}$.

15 Opinia BAS z 16 lipca 2018 r. (BAS-WAPL/WAPM 1617/18) na temat wniosku dotyczącego rozporządzenia Parlamentu Europejskiego i Rady w sprawie finansowania 
Analiza wpływu projektowanego aktu prawnego na prawo polskie sprowadza się do wskazania tych obszarów krajowej regulacji, które będą musiały zostać dostosowane do przyszłych unormowań unijnych. Projekty aktów ustawodawczych UE zmieniają się często w znacznym stopniu w toku procedury ustawodawczej, w związku z tym uwagi dotyczące koniecznej implementacji mają najczęściej charakter ramowy, nawiązują do - ujętej w merytorycznej części oceny dokumentu UE - informacji o stanie prawa polskiego, które dotyczy materii objętych treścią dokumentu UE, i zawierają wskazówki dotyczące ustaw krajowych, które musiałyby (lub mogłyby) się zmienić w przypadku wejścia w życie projektowanego aktu prawnego. Uwagi tego typu dotyczą wszystkich kategorii aktów prawnych UE - zaangażowanie ustawodawcy polskiego może być konieczne nie tylko w przypadku transpozycji dyrektyw unijnych, lecz także implementacji rozporządzeń i decyzji.

Kwalifikacje proceduralne mają wpływ na sposób rozpatrywania danego dokumentu UE w Sejmie. Ze względu na możliwości oddziaływania na tok - i rezultat - postępowania prawotwórczego w UE, Komisja ds. UE interesuje się typem procedury prawodawczej, która znajduje w danym przypadku zastosowanie (zwykła, specjalna procedura ustawodawcza), oraz właściwym trybem głosowania w Radzie (jednomyślność, większość kwalifikowana). W analizie oceniany jest też etap postępowania unijnego, na którym znajduje się dany dokument UE.

Wskazane kwalifikacje proceduralne determinują tryb, w jakim danym dokumentem UE zajmuje się Komisja ds. UE, w szczególności typ opinii, który może ona w danej sprawie wydać. Uwzględniane są przy tej okazji także terminy na podjęcie działań przez Sejm - traktatowe (8 tygodni na przesłanie uzasadnionej opinii o projekcie aktu ustawodawczego UE) oraz ustawowe - np. 14 dni na przedstawienie przez Radę Ministrów projektu stanowiska w sprawie projektu aktu ustawodawczego UE (art. 7 ust. 1 ustawy kooperacyjnej). Na tym etapie analizy formułowane jest też rozstrzygnięcie w sprawie dopuszczalności podjęcia prac nad projektem uchwały Sejmu zawierającej uzasadnioną opinię o niezgodności projektu aktu ustawodawczego z zasadą pomocniczości.

\section{Podsumowanie}

W Sejmie istnieje rozbudowana procedura oceny dokumentów UE. Procedura ta wspiera się na fundamentach prawnych, traktatowych i ustawowych, w znacznej

wspólnej polityki rolnej, zarządzania nią i monitorowania jej oraz uchylającego rozporządzenie (UE) nr 1306/2013 (COM(2018) 393 final). W ocenie ekspertów BAS D. Stankiewicz, K. Kuszela: Należy [...] zaznaczyć, że Komisji przyznano uprawnienia do przyjmowania aktów delegowanych dotyczących kwestii istotnych, czyli przepisów dotyczacych minimalnych warunków akredytacji agencji płatniczych oraz jednostek koordynujących, obowiązków agencji płatniczych w odniesieniu do interwencji publicznej oraz przepisów dotyczących zakresu ich obowiązków w dziedzinie zarządzania i kontroli. 
mierze kształtowana jest jednak przez utrwalony od wielu lat zwyczaj parlamentarny. Stosowanie tej procedury pozwala na wyeksponowanie - i kompleksową ocenę - w pracach sejmowej Komisji ds. UE tych elementów unijnej regulacji, które mają znaczenie z punktu widzenia udziału Sejmu w procesie stanowienia prawa UE.

\section{Bibliografia}

Adamiec D., Prawne aspekty kontroli zasady pomocniczości przez parlamenty państw członkowskich Unii Europejskiej, Warszawa 2018.

Cieślik Z., Rola Sejmu w stanowieniu prawa Unii Europejskiej [w:] Rola Sejmu w stanowieniu i wykonywaniu prawa Unii Europejskiej, red. B. Pawłowski, Warszawa 2015.

Parlamenty narodowe wobec zasady pomocniczości w świetle prawa i praktyki Unii Europejskiej, red. C. Mik, Warszawa 2019. 